\title{
A comparative assessment of Non-destructive and destructive methods for precise volume estimation of mango (Mangifera indica) trees
}

Alka Kushwaha*

Department of Environmental Sciences, Integral University, Kursi Road, Lucknow-226026 (Uttar Pradesh), India

\section{Ashok Kumar}

Division of Crop Production, ICAR- Central Institute for Subtropical Horticulture, Rehmankhera, Lucknow-227101 (Uttar Pradesh), India

Rahila Rahman Khan

Department of Environmental Sciences, Integral University, Kursi Road, Lucknow-226026 (Uttar Pradesh), India

*Corresponding author. Email: akka0444@gmail.com

\section{Article Info}

https://doi.org/10.31018/

jans.v13i1.2480

Received: January 5, 2021

Revised: February 16, 2021

Accepted: February 22, 2021

\section{How to Cite}

Kushwaha, A. et al. (2021). A comparative assessment of Non-destructive and destructive methods for precise volume estimation of mango (Mangifera indica) trees. Journal of Applied and Natural Science, 13(1): 183 - 190. https://doi.org/1 0.31018/jans.v13i1.2480

\begin{abstract}
Terrestrial carbon sequestration is a natural process towards carbon mitigation in which perennial trees play a vital role. Total biomass of the tree can be measured by a destructive and Non-destructive method. Since tree felling is ban in India, Nondestructive measurements by allometric equations have been widely used for the estimation of tree biomass, which is derived from the destructive method. The present study focused on estimating mango (Mangifera indica) wood logs volume both by destructive and Non-destructive methods in ICAR-Central Institute of Subtropical Horticulture, Lucknow. In Non-destructive method, all required physical parameters were recorded from different positions and further calculated by $T_{2}: \log$ formula $=\pi \mathrm{h}$ $\left(r_{1}{ }^{2}+r_{2}{ }^{2}+r_{1} r_{2}\right) / 3 ; T_{3}$ : cylindrical shape formula $=\pi r^{2} h$ with mean value and $T_{4}$ : cylindrical shape formula $=\pi r^{2} h$ with maximum value. The calculated volume of mango wood logs was compared with the obtained volume by $T_{1}:$ Water displacement method. ANOVA was used to compare volume generated from several methods. The results showed that average volume obtained by $T_{2}$ and $T_{3}$ methods was found less than the $T_{1}$ method, which was $13.69 \%$ and $12.95 \%$, respectively. The volume obtained by $\mathrm{T}_{4}$ was found close to the $T_{1}$. The study minimized the error while estimating the biomass of mango trees with the essential parameter, the wood volume. Calculating the volume of major branches in the mango tree will make it easier to calculate accurate AGB by a Non-destructive method. The estimated AGB will be helpful to calculate the amount of sequestered carbon and contribution toward mitigating atmospheric carbon dioxide by mango cultivated areas.
\end{abstract}

Keywords: Destructive methods, Non-destructive methods, Physical measurements, Tree volume, Wood density

\section{INTRODUCTION}

Global forest plays a vital role in carbon storage which helps in mitigating climate change. The world forest accumulates the atmospheric carbon into their biomass and organic matter in soil (Vashum and Jayakumar, 2012). It stores atmospheric carbon in to the tree biomass during the process of photosynthesis. Some reports showed that tropical forest has stored up 50 to 55 $\%$ of carbon in terrestrial biomass (Di Porcia et al., 2019; Jones et al., 2019; Lewis et al., 2015, Aryal et al. 2014; Ngo et al. 2013;). The total carbon stock in biomass of world' forest is $289 \mathrm{Gt}$ recorded in 2010 (FAO,
2010) which includes above- below ground biomass of a tree. The quantity of world's forest biomass or plantation determines the potential of carbon which helps in conserving carbon pools and biomass production (Chauhan et al., 2019; Panwar et al., 2017; Chauhan et al., 2015; Brown et al., 1999).

In India, Lucknow, the capital of Uttar Pradesh, globally famous for their endemic mango varieties like Dashahari, Chaunsa, Langra, Lucknawi Safeda. Among the states of India, Uttar Pradesh is the second largest mango producing state after the Andhra Pradesh, which covers $2649.30 \mathrm{~km}^{2}$ (DoACans FW, 2017). The Lucknow, Sitapur, Hardoi, Barabanki and Unnao are 
main districts of Urrar Pradesh for mango cultivation in which Mal, BakshikaTalab, Kakori and Malihabad are the predominant growing areas of mango. The largest 14belts of Dashehari mangoare abundant in Malihabad of Uttar Pradesh which covers $300 \mathrm{~km}^{2}$ (Paul, 2014), which stored a lot of carbon in their entire biomass but the amount of sequestrated carbon has not been properly quantified yet which can be found by the total biomass of the tree. Biomass of a tree is estimated by the Direct and Indirect method. In the Direct method, the entire tree is harvested and the weight of each part is taken, which is also known as Destructive method.

Allometric equations (Brown, 1997) have been widely used for the estimation of tree biomass which is derived from the destructive method which being easily used on a large area (Chave et al., 2005; Malhi et al., 2006; Djomo and Chimi, 2017; Kebede and Soromessa, 2018; Altanzagas et al., 2019; Wirabuanaet al., 2020). On the other hand, the Indirect method, derived from the Direct method, also known as Non-destructive method. In Non-destructive, measurements of tree height, $\mathrm{DBH}$ (diameter at breast height), the volume of branches and wood density are the essential parameters (Brown, 1997). However, the huge error can be caused due to improper measurements while estimating biomass of a tree and inaccurate biomass did not account for actual carbon stock in the tree (Clark and Kellner, 2012; Ahmed et al., 2013; Molto et al., 2013; Shi and Liu, 2017; RouMéchainéj et al., 2017). To quantify the total amount of sequestrated carbon, measurement of the whole tree is required for which the volume and wood density are the essential parameters. Generally, tree trunk or branches are treated as paraboloid, cylinder, conoid or neiloid while calculating volume. So the volume of the tree can be obtained on the basis of formulas of these shapes, but only by changing the position of top and bottom diameter which provides variation in the volume of branches and the volume of the tree. The present study was conducted to determine the volume of wood logs by various methods and to have their comparative assessment.

\section{MATERIALS AND METHODS}

\section{Study area}

The experiment was conducted at ICAR-Central Institute for Subtropical Horticulture, Rehmankhera, POKakori, Lucknow- 226101 (Uttar Pradesh) situated at $26^{0} 45^{\prime}$ to $27^{0} 10^{\prime}$ North latitude and $80^{\circ} 30^{\prime}$ to $80^{\circ}$ $55^{\prime}$ East longitude. It falls under the humid and warm sub-tropical climatic region with alluvial soil. Due to its climatic condition, Kakori, Malihabad, Mall, Baksikatalab and nearby districts such as; Lucknow, Hardoi, Sitapur, Unnaoare favourable for mango cultivation (Fig. 1).

\section{Field measurements}

Nine grafted mango trees with same age groups (40 years old) were selected for this experiment. According to The Indian Forest Act (1927), tree felling is ban in Indiaor illegal even form personal property for any purpose. Therefore, nine primary branches were harvested with legal permission from the Department of Forest,

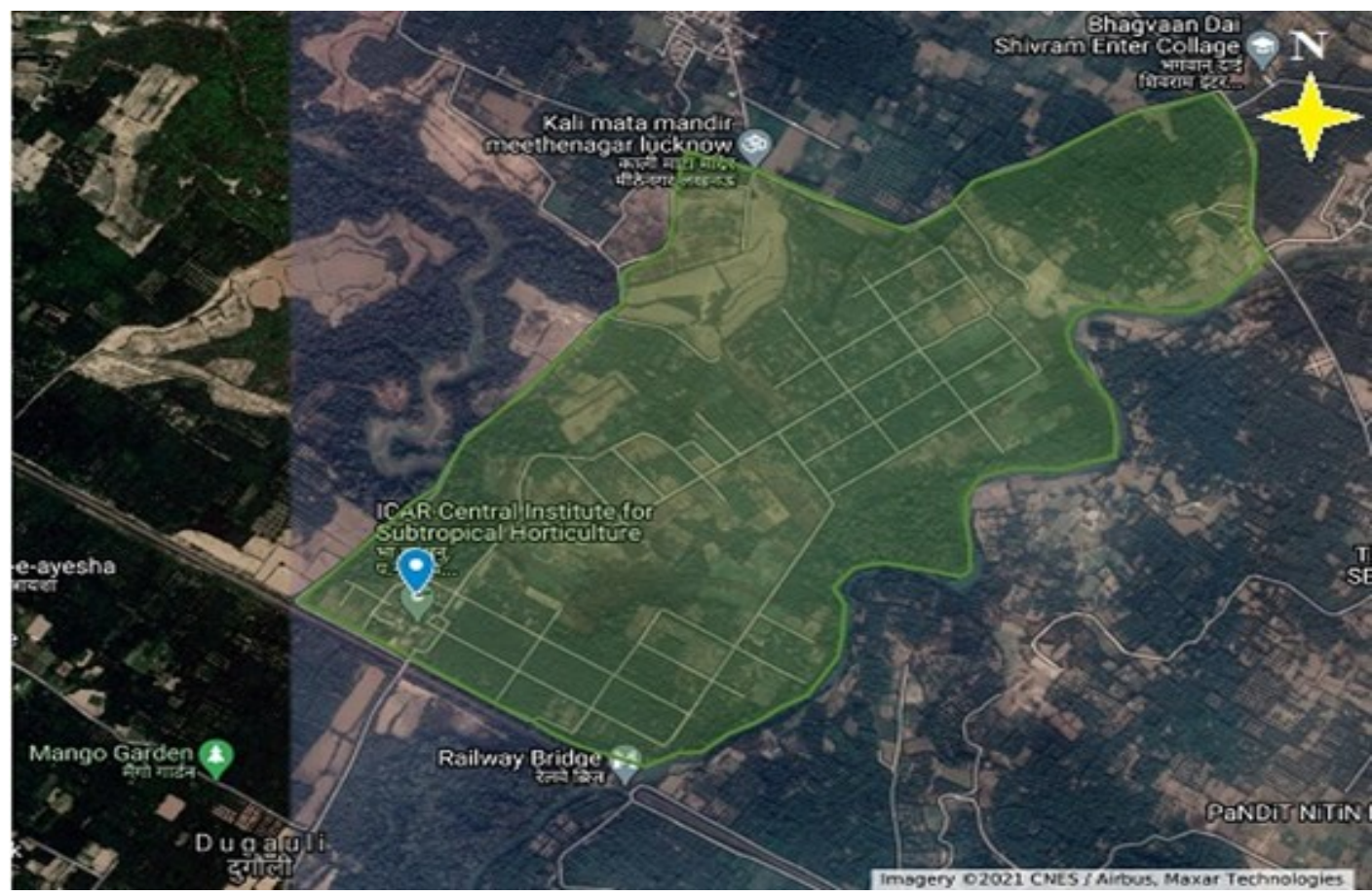

Fig. 1. Google map imagery of ICAR-Central Institute for Subtropical Horticulture, Lucknow (Uttar Pradesh) , India, Jan 2021 


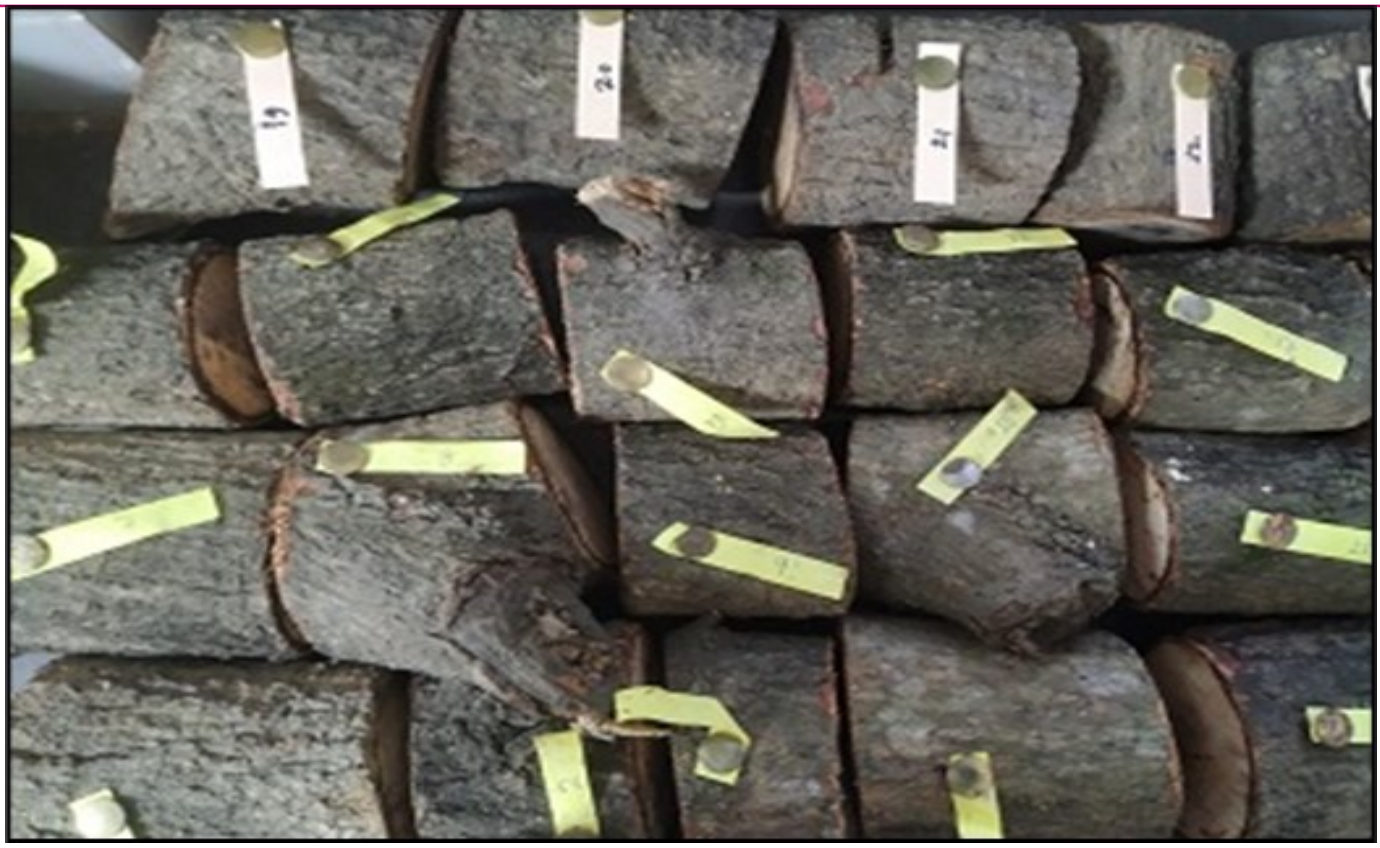

Fig. 2. Showing the pieces of Mango wood logs collected from ICAR-Central Institute for Subtropical Horticulture, Lucknow (Uttar Pradesh).

Government of Uttar Pradesh for each selected trees. All the harvested branches were further cut into the lower, middle and upper part. Total of 27 logs was collected and properly labelled with numeric series (Fig. 2). The volume of each wood logs was observed by both destructive and Non-destructive method. Further, a comparative study was done. By this experiment, it will be easier to identify which method will provide the accurate volume of major branches in the Nondestructive method.

\section{Volume of wood logs by Destructive method}

Destructive method was considered as Treatment-1 ( $T$ 1). In this method, volume of wood logs was obtained by Water displacement method with the help of cylindrical flask(ASTM, 2017). Under this process, a wood sample was immersed in a beaker filled with water. The amount of water released from the beaker when the wood submerged, was the volume of that wood. This volume of wood logs was considered as standard value by this method, because Water displacement method is considered as an accurate method for volume estimation.

\section{Volume of wood logs by Non-destructive method} In Non-destructive method, volumes were calculated by various formulas on the basis of branch's shape which were named as Treatment-2, 3 and 4 (T-2, T-3 and T4). In Non-destructive method, diameter and length of are the essential parameters for the estimation of wood log volume (Blozan. W., 2006).Therefore, maximum and average lengths were taken by geometric scale. Diameters were recorded form bottom middle and top with a tree caliper. Maximum and minimum diameter- swere also recorded (Fig. 3). Obtained values werefurther calculated by the following formulas:

Volume of woodlog $=\pi \mathrm{h}\left\{\mathrm{r}_{1}{ }^{2}+\mathrm{r}_{2}{ }^{2}+\left(\mathrm{r}_{1} \mathrm{r}_{2}\right)\right\}(\mathrm{T}-2) \quad \ldots$ Eq. 1 Where, $\pi=3.14, r_{1}=$ top radius, $r_{2}=$ bottom radius, $h=$ height (Wikipedia contributors, 2020; Hussain., 2019). Volume of cylindrical shape $=\pi r^{2} h(T-3) \quad$....Eq.2 Where, $\pi=3.14, r=$ radius (mean value), $h=$ height (mean value) (Saral et al., 2017)

Volume of cylindrical shape $=\pi r^{2} h(T-4) \quad$....Eq.3 Where, $\pi=3.14, r=$ radius (max. value), $h=$ height (max. value)

\section{Statistical analysis}

For statistical analysis purpose, One-way ANOVA and MS excel were used. Histographic presentation and frequency distribution was derived from MS excel. Required graphs were plotted from MS excel.

\section{RESULTS}

\section{Physical observations for Non-destructive methods} Physical parameters; diameter and length were recorded for the estimation of mango wood log volume. Histographic distribution showed a maximum frequency level of bottom diameter as $10.47 \mathrm{~cm}, 8.89 \mathrm{~cm}$ of top diameter and 10.47 of maximum diameter. Diameters of the wood log were ranging between 7.2 to $11.8 \mathrm{~cm}$ and their lengths were 6.2 to $15 \mathrm{~cm}$. Mean diameters varying between 7.23 to $11.20 \mathrm{~cm}$ and average lengths of log varied from 6.2 to $14.65 \mathrm{~cm}$ (Fig.4).

\section{Treatment-1}

In T-1 (destructive method), fresh weight of logs (with 3 replications) was taken before the volume was record- 
Kushwaha, A. et al. / J. Appl. \& Nat. Sci. 13(1): 183 - 190 (2021)

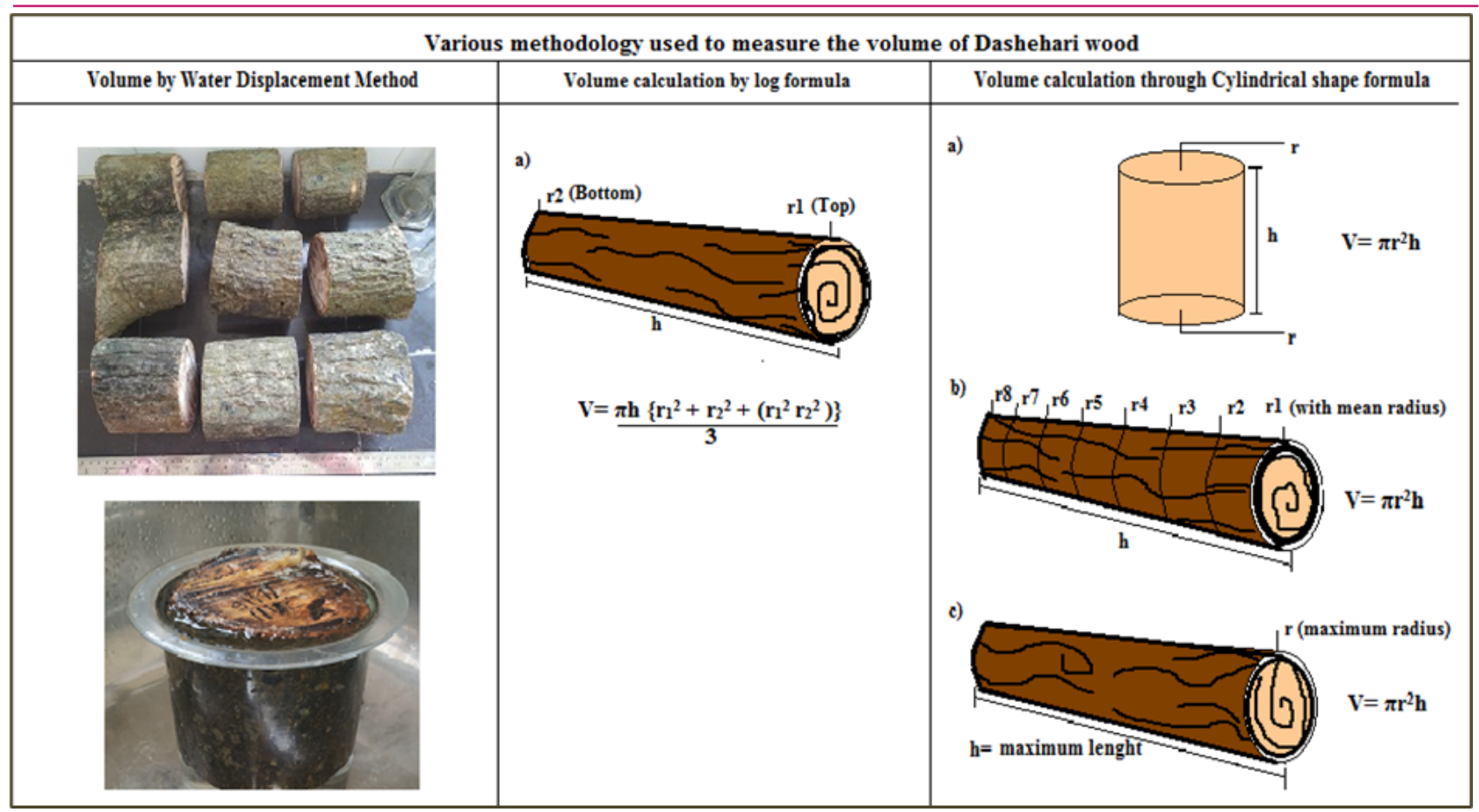

Fig. 3. Methods, followed in this experiment for the estimation of wood volume.
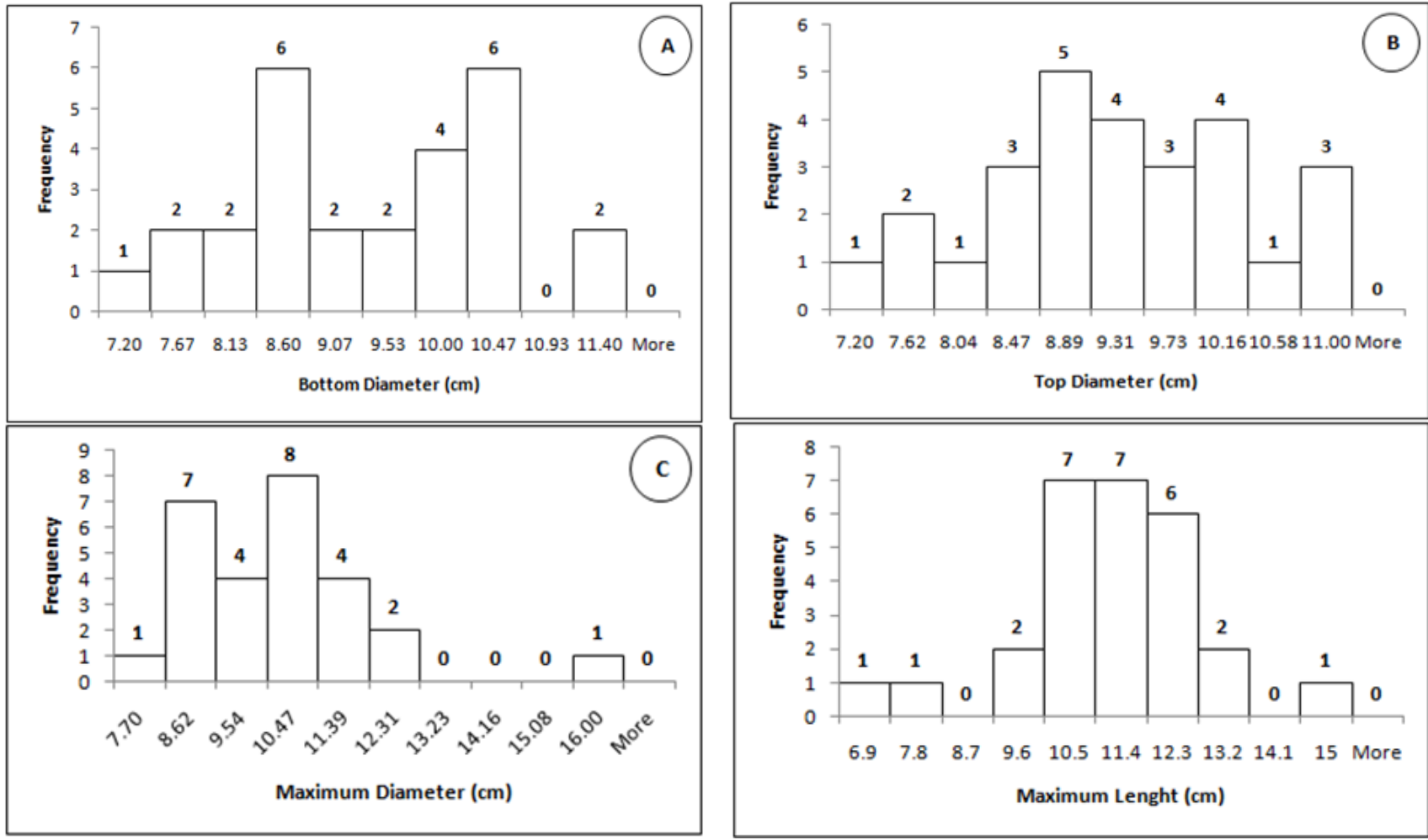

Fig. 4. Histographic distribution of essential parameters for the estimation of mango wood logs: A, Bottom diameter (cm); $\boldsymbol{B}$, Top diameter (cm); C, Maximum diameter $(\mathrm{cm}) ; \boldsymbol{D}$, Maximum length $(\mathrm{cm})$.

ed by Water displacement method. Weight of logs ranged between 580 to 1367.5 grams and volumes were between 465 to $1430 \mathrm{~cm}^{3}$ (Fig. 6). In mango trees, the fresh weight of all branches was found less than the volume of their branches (Fig.5). Most of the wood logs were found floating on the upper surface of the water (Fig.3), but some samples were found drowning in the beaker. This type of pattern was only found in the bottom part of the primary branches. Maximum volume was found in $1^{\text {st }}$ branch and the minimum was in $9^{\text {th }}$ branch.

\section{Treatment-2}




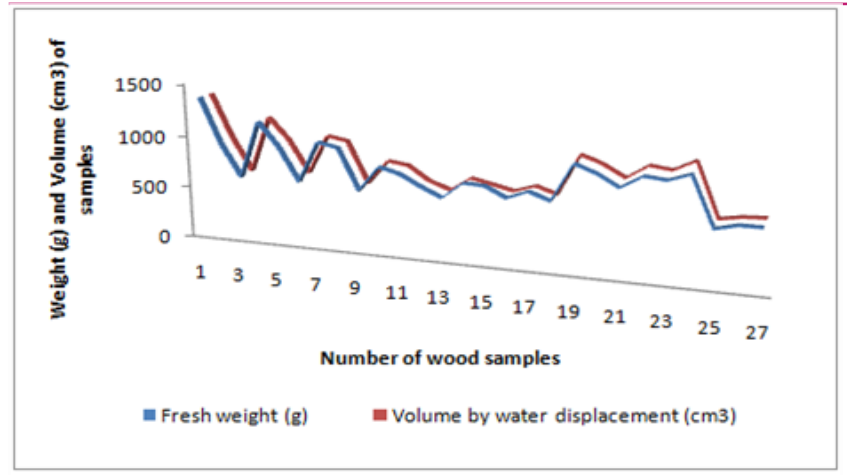

Fig. 5. Fresh weight and volume of the Mango woods.

In T-2 (Non-destructive method), volume of wood logs was calculated with wood log formula $\pi \mathrm{h}\left\{\mathrm{r}_{1}{ }^{2}+\mathrm{r}_{2}{ }^{2}+\right.$ $\left.\left(r_{1} r_{2}\right)\right\} / 3$. For this formula, average height/length $(h)$ was considered and radius was taken from top and bottom which were named as $r_{1}$ and $r_{2}$ respectively. The average length of wood logs was ranging from 6.2 to $11.4 \mathrm{~cm}$. The radius of the top part $\left(r_{1}\right)$ was obtained between 7.4 to $10.9 \mathrm{~cm}$ and bottom part $\left(r_{2}\right)$ was between 7.4 to $11 \mathrm{~cm}$ (Fig.6). Calculated volumes of wood logs wereranging from 429.79 to $915.75 \mathrm{~cm} 3$. Maximum volume was found in $1^{\text {st }}$ branch and minimum volume was found in $9^{\text {th }}$ branch (Fig. 7).

\section{Treatment-3}

In T-3 (Non-destructive method), the volume of wood logs was calculated with the cylindrical shape formula $=$ $\pi r^{2} h$ in which mean values of the radius (radius from the bottom, middle and top positions) and the average length of each log. The average length of wood logs ranged from 6.2 to $11.4 \mathrm{~cm}$, and the mean radius ( $r$ ) was ranging from7.1 to $10.91 \mathrm{~cm}$. Calculated volumes of wood logs were found between 427.86 to 944.21 cm3 (Fig. 8). Maximum and minimum volume was found same as T-2.

\section{Treatment-4}

In T-4 (Non-destructive method), the volume of wood logs was calculated with the cylindrical shape formula= $\pi r^{2} h$ in which maximum length and maximum radius

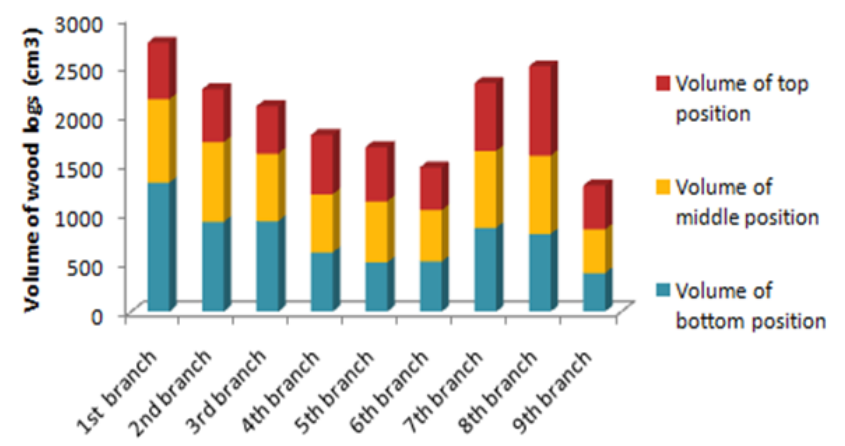

Fig. 7. Volume of branches by $T 2 ; \pi h\left\{r_{1}{ }^{2}+r_{2}{ }^{2}+\left(r_{1} r_{2}\right)\right\} / 3$.

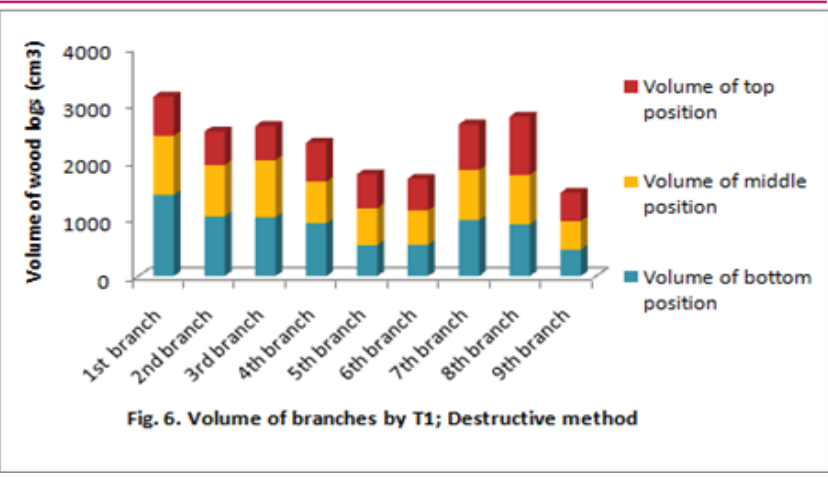

Fig. 6. Volume of mango wood logs as measured by $T 1$ method.

were considered. Maximum radius was found somewhere else between the logs instead of top or bottom position. Therefore, in $\mathrm{T}-4$ radius and length were noted at the maximum position for the estimation of woods volume. So, the maximum length was varying from 10.5 to $11.67 \mathrm{~cm}$ and maximum radius was varying from 7.8 to $11.7 \mathrm{~cm}$. The volume of wood logs were calculated between 501.65 to $1080.41 \mathrm{~cm} 3$ (fig. 9). Minimum volumes of wood logs were found the same as the treatments T-1, T-2 and T-3, but maximum volume was not similar. Maximum volume was found in $3^{\text {rd }}$ branch due to its irregular shape and size (fig. 10).

\section{DISCUSSION}

Volumes of wood logs obtained by T-1 were considered as standard values. Most of the wood logs were found floating, but some were drowned in the beaker while measuring volume by the Water Displacement method. The bottom part of each primary branch was only found submerged in water, which showed that the wood density of drowned logs was higher than the other logs. Value of wood density varies within the tree and decreases with increasing height (king et al., 2006; Gupta et al.,2017; Kushwaha et al., 2019). The volume of wood logs was increased with their fresh weight which showed inverse nature. Volume obtained by T-2 and T3 was found less than the T-1, which was $13.69 \%$ and $12.95 \%$, respectively. The volume of wood logs by T-2

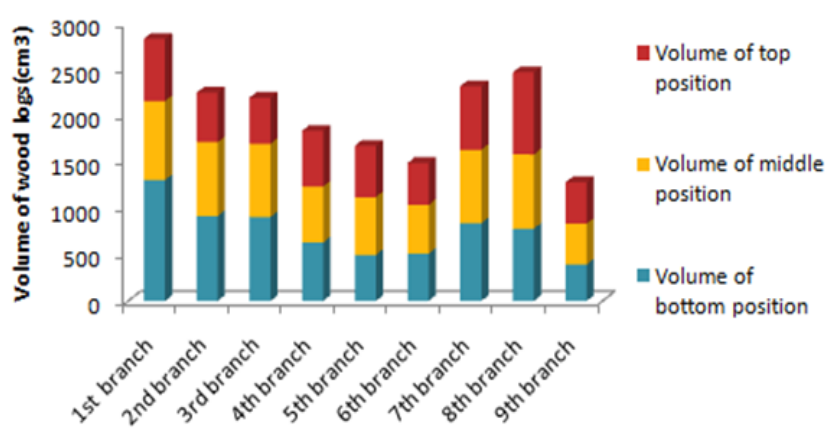

Fig. 8. Volume of branches by $T 3 ; \pi r^{2} h$ (mean radius \& length). 


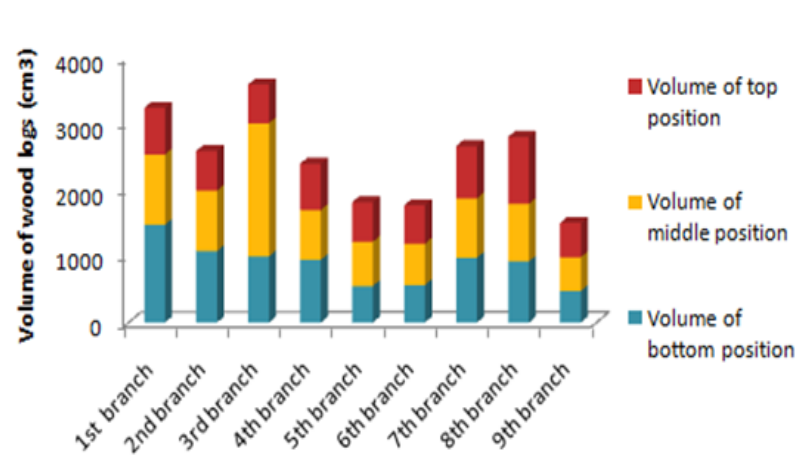

Fig. 8. Volume of branches by $T 4 ; \pi r^{2} h$ (maximum radius \& length).

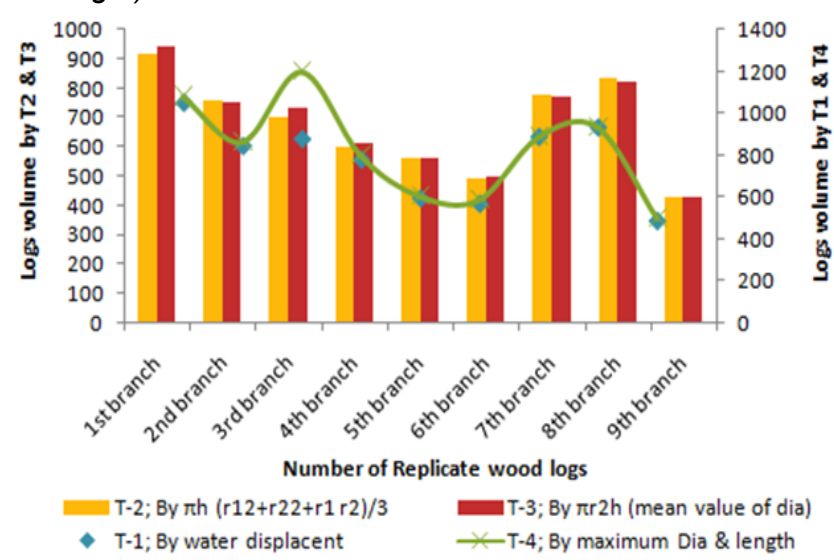

Fig. 11. Comparative analysis of T1, T2, T3 and T4.

and T-3 were found almost similar to each other which represents that the average radius ( $r$ ) and top and bottom radius $\left(r_{1}\right.$ and $r_{2}$ ) of any mango branch will give approximately same volume, but,considering mean radius or top and bottom radiuswill cause major error in while calculating the volume of the mango tree.

Although wood logs were uniform, there was variation in physical measurements after cutting primary branches into small pieces. In most of the samples, the maximum diameter was not found at the bottom, top or middle position. So, the radius was recorded at the position where the maximum. The volume of wood logs by T-4 was found to be higher than all treatments but close to the T-1. Although the volume of wood logs was found similar by $\mathrm{T}-1$ and $\mathrm{T}-4$, the irregular shape and size of the 3rd branch were found higher (Fig.11). So, the average volume of wood logs calculated by T-4 was $5.79 \%$ higher than T-1.

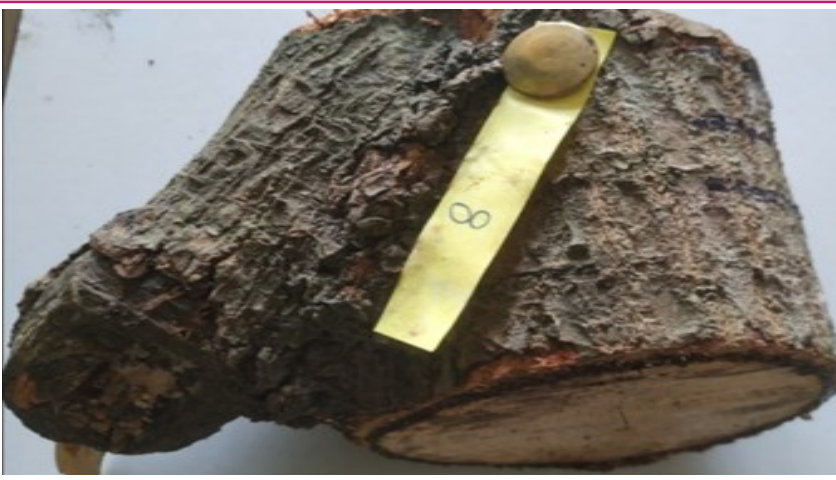

Fig. 10. Shape of $R 3$ wood log in $3^{\text {rd }}$ branch.

ANOVA for estimation of wood logs volume using four different methods is given in Table 1 . Due to the variation in diameter within the wood logs, an insignificant variance was found in the average volume of wood logs. The level of wood log volumes while estimating by various methods had an insignificant impact on the result, $F(3,32)=1.46, p=0.24(p>0.05)$. Therefore, instead of considering mean radius or $r_{1}$ and $r_{2}$ of the radius at the top and bottom part, the radius at the maximum point will provide better result while estimating the volume of mango tree branches by Nondestructive method. Most of the earlier reports had considered the volume of the whole tree through $\mathrm{DBH}$ and tree height instead of the volume of all separate branches of that particular tree while estimating the potential of carbon sequestration through above-ground biomass (AGB) (Saral. et al., 2017; ChavanandRasal., 2010; 2011; 2012; Suryawanshi et al., 2014; Salunkha. et al., 2016) which can cause a huge error in the mango tree. These above findings will reduce the error percentage while estimating the volume of standing tree by Non-destructive method. So, instead of taking diameter at the top and bottom position, diameter at the maximum position will give accurate volume in mango wood logs. Further, the volume of major branches will be used to develop allometric equations based on precise data while estimating above ground biomass and the amount of sequestrated carbon through mango tree.

\section{Conclusion}

The present study concluded that among four comparative assessments for précising volume estimation of

Table .1. ANOVA for estimation of wood logs volume using four different methods.

\begin{tabular}{lllll}
\hline & \multicolumn{2}{c}{ SUMMARY } \\
Groups & Count & Sum & Average & Variance \\
\hline $\mathrm{T}-1 ;$ By water displacement & 9 & 7031.32 & 781.26 & 35678.37 \\
$\mathrm{~T}-2 ;$ By $\pi \mathrm{h}\left(\mathrm{r}_{1}{ }^{2}+\mathrm{r}_{2}{ }^{2}+\mathrm{r}_{1} \mathrm{r}_{2}\right) / 3$ & 9 & 6068.71 & 674.30 & 26766.39 \\
$\mathrm{~T}-3 ;$ By $\pi \mathrm{r} 2 \mathrm{~h}$ (mean value of dia) & 9 & 6120.11 & 680.01 & 27861.29 \\
T-4; By maximum Dia and length & 9 & 7463.36 & 829.26 & 53817.63 \\
\hline
\end{tabular}


mango ( $M$. Indica) branches, the volume by $\pi r^{2} h$ with the maximum value of radius and length was found more efficient than the log formula $=\pi \mathrm{h}\left(\mathrm{r}_{1}{ }^{2}+r_{2}{ }^{2}+r_{1} r_{2}\right) / 3$ and cylindrical shape formula $=\pi r^{2} h$ with mean radius and length. Cylindrical shape formula with a maximum value of radius and log length was effective measurement compared to other formulas for reducing error while estimating the volume of the wood log by Nondestructive method. The study will be an effective and environmental approach for estimating above-ground biomass of standing mango trees. Further, this can be used to account for total sequestrated carbon through biomass of mango trees.

\section{ACKNOWLEDGEMENTS}

Authors are thankful to The Head, Department of Environmental Sciences, Integral University, Lucknow, India for providing necessary facilities, and also thankful to Dr. S. Rajan, Director of ICAR-Central Institute for Sub-tropical Horticulture, Rahmankhera, Lucknow (Uttar Pradesh), India for providing necessary facilities and valuable suggestions.

\section{Conflict of interest}

The authors declare that they have no conflict of interest.

\section{REFERENCES}

1. Ahmed, R., Siqueira, P., Hensley, S., and Bergen, K. (2013). Uncertainty of forest biomass estimates in north temperate forests due to allometry: Implications for remote sensing. Remote Sensing, 5(6), 3007-3036. https://doi.o $\mathrm{rg} / 10.3390 / \mathrm{rs} 5063007$

2. Altanzagas, B., Luo, Y., Altansukh, B., Dorjsuren, C., Fang, J., and Hu, H. (2019). Allometric equations for estimating the above-ground biomass of five forest tree species in Khangai, Mongolia. Forests, 10(8), 661. https:// doi.org/10.3390/f10080661

3. Aryal, D. R., De Jong, B. H., Ochoa-Gaona, S., EsparzaOlguin, L., and Mendoza-Vega, J. (2014). Carbon stocks and changes in tropical secondary forests of southern Mexico. Agriculture, Ecosystems and Environment, 195, 220-230.https://doi.org/10.1016/j.agee.2014.06.005

4. ASTM. (2017). Standard test methods for specific gravity of wood and wood-based materials. Edition D 2395-17. Philadelphia, USA. pp 353-360

5. Blozan, W. (2006). Tree measuring guidelines of the eastern native tree society. Bulletin of the Eastern Native Tree Society, 1(1), 3-10.

6. Brown S. (1997). Estimating biomass and biomass change of tropical forests: a primer. Food and Agriculture Org. 134. ISSN: 0258-6150

7. Brown, S. L., Schroeder, P., and Kern, J. S. (1999). Spatial distribution of biomass in forests of the eastern USA. Forest Ecology and Management, 123(1), 81-90. https://doi.org/10.1016/S0378-1127(99)00017-1

8. Chavan, B. L., andRasal, G. B. (2010). Sequestered standing carbon stock in selective tree species grown in University campus at Aurangabad, Maharashtra, India. International Journal of Engineering Science and Technology, 2(7), 3003-3007. ISSN: 0975-5462

9. Chavan, B., and Rasal, G. (2012). Total sequestered carbon stock of Mangifera indica. Journal of Environment and Earth science, 2(1), 37-48. ISSN: 2249-4596

10. Chavan, B. L., and Rasal, G. B. (2011). Potentiality of Carbon Sequestration in six year ages young plant from University campus of Aurangabad. Global Journal of Research In Engineering, 11(7-C), 15-20. ISSN: 2225-0948

11. Chauhan, S. K., Singh, S., Sharma, S., Sharma, R., andSaralch, H. S. (2019). Tree biomass and carbon sequestration in four short rotation tree plantations. Range Manag. Agrofor, 40, 77-82.

12. Chauhan, S. K., Sharma, R., Singh, B., and Sharma, S. C. (2015). Biomass production, carbon sequestration and economics of on-farm poplar plantations in Punjab, India. Journal of Applied and Natural Science, 7(1), 452458. https://doi.org/10.31018/jans.v7i1.631

13. Chave, J., Andalo, C., Brown, S., Cairns, M. A., Chambers, J. Q., Eamus, D., andLescure, J. P. (2005). Tree allometry and improved estimation of carbon stocks and balance in tropical forests. Oecologia. 145(1), 87-99. https://doi.org/10.1007/s00442-005-0100-x

14. Clark, D. B., and Kellner, J. R. (2012). Tropical forest biomass estimation and the fallacy of misplaced concreteness. Journal of Vegetation Science, 23(6), 1191-1196.

15. Djomo, A. N., andChimi, C. D. (2017). Tree allometric equations for estimation of above, below and total biomass in a tropical moist forest: Case study with application to remote sensing. Forest Ecology and Management, 391, 184-193. https://doi.org/10.1016/j.foreco.201 7.02.022

16. Di Porcia E Brugnera, M., Meunier, F., Longo, M., Krishna Moorthy, S. M., De Deurwaerder, H., Schnitzer, S. A., and Verbeeck, H. (2019). Modeling the impact of liana infestation on the demography and carbon cycle of tropical forests. Global change biology, 25(11), 3767-3780. https:// doi.org/10.1111/gcb.14769

17. FAO. (2010). Global Forest Resources Assessment. Country report: United Republic of Tanzania, Dar es Salaam, Tanzania. 56pp.

18. Gupta, D. K., Bhatt, R. K., Keerthika, A., Shukla, A. K., Noor Mohamed, M. B., andJangid, B. L. (2017). Wood specific gravity of trees in hot semi-arid zone of India: Diversity among species and relationship between stem and branches. Current Science. 113(8), 1597-600. https:// doi.org/ 10.18520/cs/v113/i08/1597-1600

19. Hussain, S. (2019). How to Calculate the Cubic Feet of a Log" sciencing.com, https://sciencing.com/calculate-cubicfeet-log-6527592.html. 15 December 2020

20. Jones, I. L., DeWalt, S. J., Lopez, O. R., Bunnefeld, L., Pattison, Z., and Dent, D. H. (2019). Above-and belowground carbon stocks are decoupled in secondary tropical forests and are positively related to forest age and soil nutrients respectively. Science of The Total Environment, 697, 133987. https://doi.org/10.1016/j.scitotenv.201 9.133987

21. Kebede, B., andSoromessa, T. (2018). Allometric equations for aboveground biomass estimation of Olea europaea L. subsp. cuspidata in ManaAngetu For- 
est. Ecosystem Health and Sustainability, 4(1), 1-12. https://doi.org/10.1080/20964129.2018.1433951

19. King, D. A., Davies, S. J., Tan, S., and Noor, N. S. M. (2006). The role of wood density and stem support costs in the growth and mortality of tropical trees. Journal of Ecology. 94(3), 670-680. https://doi.org/10.1111/j.1365-27 45.2006.01112.x

20. Kushwaha, A., Kumar, A., and Khan. R.R. (2019). Developing an indirect method for tree volume estimation of mango Cultivar Dashehariin Abstracts of Progressive Horticulture Conclave (PHC-2019) on Futuristic Technologies in Horticulture, Indian Society of Horticultural Research and Development (ISHRD), Uttarakhand, during December 8-10, 2019, held at ICAR-Indian Institute of Sugarcane Research, Lucknow, India. Misra et al., (ed.) (2019). P-72.

1. Lewis, S. L., Edwards, D. P., and Galbraith, D. (2015). Increasing human dominance of tropical forests. Science, 349(6250), 827-832. https://doi.org/10.1 126/science.aaa9932

2. Malhi, Y., Wood, D., Baker, T. R., Wright, J., Phillips, O. L., Cochrane, T., and Higuchi, N. (2006). The regional variation of aboveground live biomass in old $\square$ growth Amazonian forests. Global Change Biology, 12(7), 11071138. https://doi.org/10.1111/j.1365-2486.2006.01120.x

3. Molto, Q., Rossi, V., and Blanc, L. (2013). Error propagation in biomass estimation in tropical forests. Methods in Ecology and Evolution, 4(2), 175-183. https://doi.org/10.11 11/j.2041-210x.2012.00266.x

4. Ngo, K. M., Turner, B. L., Muller-Landau, H. C., Davies, S. J., Larjavaara, M., bin Nik Hassan, N. F., and Lum, S. (2013). Carbon stocks in primary and secondary tropical forests in Singapore. Forest Ecology and Management, 296. 81-89. https://doi.org/10.1016/j.foreco.2013.02.004

5. Panwar, P., Chauhan, S., Kaushal, R., Das, D. K., ARORA, G., CHATURVEDI, O. P., and TEWARI, S. (2017). Carbon sequestration potential of poplar-based Agroforestry using the CO2FIX model in the Indo-Gangetic Region of India. Tropical Ecology, 58(2). ISSN: 0564-3295

6. Paul. S. (2014). Malihabad: In the land of famous Dussehri mangoes. Hindustan times. Downloaded on $20^{\text {th }}$ Aug 2020 from www.hindustantimes.com/brunch/ malihabad-in-the-land-of-famous-dussehri mangoes/story-
eK976k3RHWo4HSeLjTLrAL.html

7. Rou $\square$ Méchainéj, M., Tanguy, A., Piponiot, C., Chave, J., andHérault, B. (2017). biomass: An r package for estimating above ground biomass and its uncertainty in tropical forests. Methods in Ecology and Evolution, 8(9), 11631167. https://doi.org/10.1111/2041-210X.12753

8. Salunkha, O., Khare, P. K., Sahu, T. R., and Singh, S. (2016). Estimation of tree biomass reserves in tropical deciduous forests of Central India by Non-destructive approach. Tropical Ecology, 57(2), 153-161. ISSN: 05643295

9. Saral, A. M., Steffy Selcia, S., and Devi, K. (2017). Carbon storage and sequestration by trees in VIT University campus. In IOP Conference Series: Materials Science and Engineering (Vol. 263, p. 022008). https://doi.org/10.10 88/1757-899X/263/2/022008

10. Shi, L., and Liu, S. (2017). Methods of estimating forest biomass: A review. Biomass Volume Estimation and Valorization for Energy, 10, 65733. https://doi.org/10 .57 $72 / 65733$

11. Suryawanshi, M. N., Patel, A. R., Kale, T. S., and Patil, P. R. (2014). Carbon sequestration potential of tree species in the environment of North Maharashtra University Campus, Jalgaon (MS) India. Bioscience Discovery, 5(2), 175179. ISSN: 2231-024X

12. The Indian Forest Act, 1927. Downloaded on 2rd Jan 2020 from, http://nbaindia.org/uploaded/Biodiversityindia/ Legal/3.\%20Indian\%20forest\%20act.pdf.

13. Vashum, K. T., and Jayakumar, S. (2012). Methods to estimate above-ground biomass and carbon stock in natural forests-a review. Journal of Ecosystem andEcography, 2(4), 1-7. https://doi.org/10.4172/2157-7625.1000116

14. Wikipedia contributors (2020). Tree measurement. In Wikipedia, The Free Encyclopedia. Retrieved 06:38, December 15, 2020, from https://en.wikipedia.org/w/ index.php?title=Tree_measurementandoldid=991879163

15. Wirabuana, P., Setiahadi, R., Sadono, R., Lukito, M., Martono, D. S., and Matatula, J. (2020). Allometric equations for estimating biomass of community forest tree species in Madiun, Indonesia. Biodiversitas Journal of Biological Diversity, 21(9). DOI: 10.13057/biodiv/d210947 